\title{
Woman's Identity vs. Beauty Ideals: A Comparative Study of Selected Contemporary Novels
}

\author{
Marwa G. Mohammed \\ Department of English, College of Education for Women, University of Baghdad, Baghdad, Iraq
}

\begin{abstract}
Cultural notions about woman's identity play a role in woman self-acceptance and self- worth. Generally speaking, these ideas affected women since they have shaped their feelings of worth and beauty. Nowadays pursuit of beauty ideal has become one of the problematic issues to meet particular standards. Moreover, the development of selfhood is influenced by the mirror of the society. Ethnicity, body shape, skin colour, age, and wrinkles are various forms of society standards of beauty which some women shape their identities by modifying accordingly. Thus, beauty ideals become a form of restriction and enslavement because women are forced to follow and sometimes suffer to have the sense of belonging. Three novels are selected in this paper to study the problematic issue of what is meant by beauty ideal. Lucy Grealy's Autobiography of the Face (1994) depicts the suffering of a woman who has a struggle with jaw cancer since early childhood. Surviving the cancer means removing part of her jaw which causes the tragedy of her life. Zadie Smith's The White Teeth (2000) is a work about the postcolonial society of London where Irie considers herself British despite her dark skin due to her Jamaican roots. White skin is one of the ideals of beauty according to the British standard. Ellen Hopkins' Perfect (2011) is a novel in which the writer asks the question who defines the word 'perfect', the question is asked through Kendra whose dream is to be a model and a star.
\end{abstract}

Index Terms - Assimilation, beauty myth, belonging, identity, perfection, society mirror standards.

\section{INTRODUCTION}

Throughout time women's identities have been affected by beauty myth globally as it has shaped their feelings of worth and beauty. OED (2006) defined beauty as "a combination of qualities that is very pleasing to the senses or the mind". Accordingly, beauty is not only external, it is internal, too. Yet, women are misled by shaping their identities depending on the physical appearance only. In her book, The Beauty Myth (2002), Naomi Wolf discusses how female beauty becomes a way of enslavement that contradicts female liberation. Having a perfect body and losing ten to fifteen pounds are the main goals rather than accomplishing their dreams as have been stated by thirty-three American women. How women think about themselves physically is more important than having power, money, and scope (10). The concern about the physical shape decreases the sense of successful achievement. In fact, ideals of beauty cause "a dark vein of self-hatred, physical obsessions, terror of aging, and dread of lost control" (Wolf, 2002, 10). Many successful powerful women start to feel the same.

Zed Nelson in Love Me (2009) stated that "Beauty is a 160a-year global industry. The worldwide pursuit of body improvement has become a new religion" (8). Advertising campaigns and a commercially-driven Western media play a role in increasing the quest of bodily improvement. In fact, the industry of beauty becomes a process of westernizing the human body in a global way (Nelson, 2009, 8). Media and social marketing are reasons for women's obsession with thinness and body image as it is connected with self-esteem. Age and how to look young is another demand of beauty. All of these elements cause women not to have confidence in their shape. Moreover, the pursuit of mono-culturalism and assimilation demands women to change their ethnic identities; such as an ethnic nose, colour of skin, or nature of hair. Thus, women's particular identities are threatened by various society requirements. Society acceptance pushes women to shape their identities and self-esteem accordingly. (Okopoy, 2005).

Wolf (2002) connects the notion of beauty myth with the power and control of men over women. She defines beauty as:

A currency system like the gold standard. Like any economy, it is determined by politics, and in the modern age in the West it is the last, best belief system the keeps male dominance intact. In assigning value to women in a vertical hierarchy, it is expression of power relations in which women must unnaturally compete for resources that men have appropriated for themselves. (9).

A comparative study is conducted in three selected novels to examine the forces of society upon each of the three main female characters to adhere to the beauty ideals and form their own identities accordingly.

Journal of University of Human Development

Volume 5 No. 3(2019); DOI: 10.21928/juhd.v5n3y2019.pp87-90

Regular research paper: Published 21 July 2019

Corresponding author's e-mail: marwa_grery@coeduw.uobaghdad.edu.iq

Copyright (02019 Marwa G. Mohammed. This is an open access article distributed under the Creative Commons Attribution License

(CC BY-NC-ND 4.0) 


\section{LUCY GREALY'S AUTOBIOGRAPHY OF A FACE}

Lucy Grealy's Autobiography of a Face (1994) is based on the true story of the writer's struggle with cancer and the deformity of her jaw which is consequently associated to her self-image. When she was nine years old in 1972, Lucy Grealy had a toothache after a fall at school. Eventually the doctors diagnosed that it was not a toothache but a rare form of cancer in her jaw. For the rest of her life Grealy struggled with its consequences. After four years of surgery, Grealy found herself left with a disfigured face in which almost half of her jaw is removed. Throughout her life, Grealy did about thirty surgeries. Yet, the results remained the same. Moreover, she became a bird-like body because all her lower teeth gradually fallen out so she could barely eat (Lehmann-Haupt, 2002).

Later on, her family moved to the United States where she was accepted into the Iowa Writer's workshop. Writing became a refuge of her pain and a way of getting back her self-esteem. She wrote her memoir in her late twenties. The beauty of her words was her way to substitute the lack of physical beauty (Hund, 2016, 3).

In her memoir, she wrote about the cruelty of children who called her 'Dog Girl', she came to realize that "I was my face, I was ugliness" (Grealy, 2004, 7). Feeling ugly caused pain more than the pain of cancer. She considered the state of being ugly as the tragedy of her life; cancer became a minor problem in comparison. Being beautiful was associated with the feeling of acceptance by other which she was in need for it. The notation that people might regard her beautiful means that 'they might even love me' (Grealy, 2004, 20). However, this notion changed after her success as a write. In an interview she stated "As a child, I had expected my liberation to come from getting a new face to put on, but now I saw it came from shedding something, shedding my image" (Souter, 1995).

Grealy's book ends with a note of optimism because she decides to find her identity by the combination of stoicism, wit, and dignity. She changed the priorities of her life from the importance for her appearance to her determination to form her identity through her literacy powers. She faced her traumatic experiences bravely as she constructed her desired self-image to replace her distorted face (Hanscombe, 2011, 198). She said that "as a child I had expected my liberation to come from getting a new face to put on, but now I saw it came from shedding something, shedding my image" (Grealy, 2004, 222). It seems that at the end Grealy succeeded to overcome the desire to be beautiful in order to be loved.

In her memoir, Grealy depicted the mirror of culture where beauty is highly appreciated. She learnt to hear every whisper and comment about her shape:

I learned the language of paranoia; every whisper I heard was a comment about the way I looked, every laugh a joke at my expense... I was honing my selfconsciousness into a torture device, sharp and efficient enough to last me the rest of my life...there was only the fact of me, my face, my ugliness (Grealy, 2004, 6-7).

\section{ZADIE SMITH'S WHITE TEETH}

Zadie Smith's White Teeth (2000) is a postcolonial novel whose characters are searching for their identities in London with the pursuit for the sense of belonging. Irie Ambrosia Jones is a Jamaican British young women who attempts to find who she is as a woman in her contemporary society. She is a secondgeneration immigrant in England in the 1990s; having such a background causes many challenges to her, how she should look is one of the challenges she has to face. Smith sheds light on the subject of estrangement to understand the implications which immigrants have in crossing cultural boarders. Smith has succeeded in reflecting the experience of the immigrants because of her own mixed-race background and her personal encounters (Tancke, 2013, 62).

Irie is a young woman with a hyphenated identity; the sense of belonging is connected to the way she looks because of the colour of her skin. Whiteness is associated to Britishness. Toplu states that 'whiteness nowhere features as an explicit condition of being British, but it is widely understood that Englishness, and therefore by extension Britishness, is racially coded" (Toplu 2005, Cited in Arikan 2005, p.1682). Thus, secondgeneration immigrants are not recognised as British. One can understand how Irie feels. She is not white because of her Jamaican mother, and since whiteness is connected to Britishness, Irie is not treated as a British citizen (Thompson, 2005, 127).

The feeling of belonging can be associated with beauty; Jha argues that beauty "creates capacities and consciousness that open individual women as subjects to articulation of belonging" (2016, p.92). The feeling of no social worth causes Irie's selfhate and despise. Irie wishes to become an English Rose:

The mantra of the make-over junkie, sucking it in, letting it out; unwilling to settle for genetic fate; waiting instead for her transformation from Jamaican hourglass heavy with the sands that gather around Dunn River Falls, to English Rose-Oh, you know her...she's a slender, delicate thing not made for the hot suns, a surfboard rippled by the wave. (Smith, 2000, 230).

The English rose stands for beauty, whiteness, and Englishness. Irie is obsessed with her physical appearance since she is "landed... with Hortense's substantial Jamaican Frame" (Smith, 2000, 229). She is "loaded with pineapple, mangoes and guavas; the girl had big tits, big hips, big thighs, big teeth" (229). She feels that her appearance is "all wrong" (229) which is as reflection of the mirror of the British society. Thus, she is deprived of the sense of belonging because of her look. She is a stranger in what is supposed to be her own society (Thompson, 2005, 133). She tries to be like the Jamaican features in her body by wearing belly-reducing kinckers, breast reducing bra, and a meticulous lycra corseting (229). It is obvious how she is dissatisfied with her figure. She is misfit in the English society as explained in the novel: "there was England, a gigantic mirror, and there was Irie, without reflection, a stranger in a stranger land" (230).

Irie realizes that her features deprive her of being regarded as a British by her contemporary society, and of her own sense of belonging. She wants to lose weight to change her appearance 
(231). Beauty ideals prefer thinness, and Irie longs to be looked as beautiful. Thus, losing weight and diet are her means to satisfy her society. Wolf (2002) argues that this shows women bodies belong to the society more than to themselves (184).

In addition to her dissatisfaction of her Jamaican figure, she dislikes her hair and her eyes because they distinguish her from the beauty ideals of her contemporary society. Irie's father hopes that she still be born with blue eyes, yet she was born with "brown eyes" (58). Jha explains that dominant beauty standards in the US regard black women as inferior in terms of beauty. Having blue eye is generally connected to white skin as both are standards of beauty $(2016,33)$. It becomes very sensitive to Irie since her father has wished her with blue eyes. Thompson explains that Smith presents the fact that whiteness is still a dominant, and this is clarified by Irie's longing to conform to these criteria to be accepted in her society (2005, 136). Just like her weight, Irie is dissatisfied with her Afro hair, and instead she wants "straight hair, straight, straight long hair black sleek flick-able toss-able shakeable touchable fingerthrough-able wind blow-able hair" (Smith, 2000, 236). She changes her hair as her attempts of imitating whiteness is displayed. However, her attempt to straighten her hair has a negative result as her hair falls out (ibid.).

Eventually, Irie returns to Jamaica where she is no more obliged to change her appearance; she does not experience the feeling of estrangement. She learns how to reconstruct her identity away from the physical features.

\section{ELLEN HOPKINS' PERFECT}

Ellen Hopkins, who writes novels for young adult audience, deals in Perfect (2011) with four teenagers and their unrealistic goals in life. The little of the novel, Perfect, stands for the meaning of perfection for each one of them. For Cara, perfect means high grades and credits. For Kendra, it is the body image because she knows that she doesn't have the ability to achieve high grades. Sean's goal is to be the perfect player on a sports school ship. Lastly, there is Andre who dreams of being a dancer in spite of his family's objection.

Kendra's aspiring goal of being a model is what this study examines. She is a pretty young girl of 15 years old. Yet, her blond hair, blue eyes, and perfect shape is not enough to work as a model. She has to lose weight to change her size from 4 to size 2. She starts various and endless diets till she has anorexia. Her divorced mother never advices her to stop what she is doing, she does not care about her daughter, she wants her daughter to have a job and support herself so that she will not need a man to depend upon.

Culture and society play a role in the glorification of thinness. Kendra, who is the queen of pageants, does not have confidence in her perfect body size. To be a model means she starts a long process of dieting which ends by having anorexia which young women like Kendra never admits that it is disorder at all. Girls in their teens tend to start endless diet that leads to the disease of anorexia that they never admit to be a state of sickness. (Hill, 2011: 81). The idea is not about being deprived of food, it is associated with self-control, self-confidence, and socialacceptance. Media and culture contribute in the propaganda of weight loss by describing it as a state of mind control rather than appetite control. Thus, self-image or body image is a reflection of what the society demands despite its bad impacts on health and psychology (Brown, 2005: 15). Kendra attends her friend's funeral at the end of the novel with a pale face and a very thin body like a skeleton. She fails to achieve her dream of being a model. She is a victim of the beauty industry (Carpenter, 2011).

Women have different shapes and sizes. No matter how much a woman naturally or artificially changes her body to gain a specific body shape, there are some body types that will be impossible for her to have. It is a dangerous notion of popularization of model body ideal. The quest of the ideal body is not supposed to be a uniform for all women. Women today are supposed to embrace new, healthier, and suitable ideals (Matelski, 2011, 13-14).

\section{CONCLUSION}

This paper has been a comparative study of Lucy Grealy's Autobiography of the face, Zadie Smith's White Teeth, and Ellen Hopkins' Perfect in which the main female characters have the question of "who am i?" Appearance and beautiful shape become standards of forming a woman's identity. There are various reasons for the increase in the beauty ideals such as the patriarchal society, policy of assimilation, and advertising and cosmetic companies. Each one of the novels presents one of the reasons of the beauty myth; and a female who is lost. Lucy lives in a society controlled by appearance, she longs for love and acceptance which her society denies her. Irie's quest for the sense of belonging and home pushes her to change her shape. And Kendra's dream to become a model drives her to extreme diet process. They all share the same journey of finding themselves and reconstructing their identities according to the mirror of their societies, though they are different in their motives for having this quest. Their sense of the self and feeling of self-esteem are associated to the mirror of the society in which they attempt to see their own reflections.

\section{REFERENCES}

Arikan, S. (2013) 'History' and 'Root' in Zadie Smith's White Teeth. The Journal of Academic Social Science Studies. 6 (2), pp. 16791696. Available from

/http://www.jasstudies.com/Makaleler69986385_87ArıkanSeda_S1679- 1696.pdf [Accessed 04/01/17].

Brown, S. C. (2005). "Body Image Narrative: Contemporary Rhetoric of Body Shape And Size". (PhD dissertation). University of Maryland University College:Maryland.

Carpenter, S. (2011). "Perfect by Ellen Hopkins". Los Angeles Times. https://www.latimes.com/entertainment/la-xpm-2011-sep-30-la-etbook-20110930-story.html. Retrieved 13 January, 2019.

Grealy, L. (2004). Autobiography of a Face. London: Methuen.

Hanscombe, E. (2011). "Life Writing and The Desire for Revenge". (PhD dissertation).La Trobe University: Melbourne.

Hill, R. (2011). "Taking a Closer Look: Ellen Hopkins and Her Novels". The Allan Review. DOI: 10.21061/alan.v38i2.a.11.

Hopkins, E. (2011). Perfect. New York: Margaret K. McElderry Books.

Hund, S. (2016). "Putting on a Brave Face: The Creation of the Heroin in Lucy Grealy's Autobiography”. Beauty in American Literature and Culture. Pp. 1-11.

Jha, M. R. (2016). The Global Beauty Industry. Oxon: Taylor \& Francis.

Lehmann-Haupt, C. (2002). "Lucy Grealy, 39, Who Wrote a Memoir on her Disfigurement”. New York Times.

https://www.nytimes.com/2002/12/21/arts/lucy-grealy-39-who-wrote-amemoir-on-her-disfigurement.html. Retrieved 23 December, 2018.

Matelski, E. M. (2011). "The Color(s) of Perfection: The Feminine Body, Beauty Ideals, And Identity in Postwar America", 1945-1970. (PhD Dissertation). Loyola University: Chicago.

Nelson, Zed. (2009). Love Me. Constrasto, illustrated edition. 
Okpony, C.L. (2005). “Reconstructing Women's Identities: The

Phenomenon of Cosmetic Surgery in the United States". (Master's Thesis). University of South Florida:

Miami.

Smith, Z. (2000). The White Teeth. 7th edn. London: Penguin Books.

Souter,T. (1995). 'Take a good look at my face', The Guardian.

<http://www.guardian.co.uk/books/1995/feb/16/biography/print>, retrieved 12

February, 2019.

Tancke, U. (2013). "White Teeth Reconsidered: Narrative Deception and Uncomfortable Truths". In Philip Tew (ed.). Reading Zadie Smith, The First Decade and Beyond. London: Bloomsbury. pp. 62-84.

Thompson, M. (2005). "Happy Multicultural Land? The Implications of an Excess of Belonging in Zadie Smith's White Teeth". In Kadjia George \& Kadija Sesay (eds.). Write Black, Write British: from Post-Colonial to Black British Literature. London: Hansib. (pp 122-140).

Wolf, N. (2002). The Beauty Myth: How Images of Beauty Are Used Against Women. New York: Harper Collins e- book. 